\title{
Soil management and production of Alfisols in the semi-arid tropics. I. Modelling the effects of soil management on runoff and erosion
}

\author{
M. Littleboy, ${ }^{\mathrm{A}}$ A. L. Cogle, ${ }^{\mathrm{B}}$ G. D. Smith, ${ }^{\mathrm{C}}$ D. F. Yule, ${ }^{\mathrm{D}}$ and K.P.C. Rao ${ }^{\mathrm{E}}$ \\ ${ }^{A}$ Queensland Department of Primary Industries, \\ Meiers Road, Indooroopilly, Qld 4068. \\ ${ }^{B}$ Queensland Department of Primary Industries, PO Box 1054, \\ Mareeba, Qld. 4990. \\ c Queensland Department of Primary Industries, PO Box 102, Toowoomba, Qld 4350. \\ D Queensland Department of Primary Industries, \\ PO Box 6014, Rockhampton MC, Qld 4702. \\ E Resource Management Program, International Crops Research Institute \\ for the Semi-Arid Tropics (ICRISAT), Patancheru, 502324, \\ Andhra Pradesh, India.
}

\begin{abstract}
Techniques to simulate effects of surface cover and tillage on runoff and erosion are described. Data for 15 soil management treatments on an Alfisol in the semi-arid tropics, India, were used to modify existing procedures of runoff prediction using USDA runoff curve numbers. A relationship between surface cover and curve number was developed to account for the effects of surface cover on runoff. Impact of shallow or deep tillage was predicted using functions that relate curve number to cumulative rainfall since tillage. The derived relationships were applied to adjust curve number due to the effects of cover and tillage on a daily basis and were incorporated into the cropping systems model called PERFECT-IND.

Results of model validation showed that PERFECT-IND explained between 71 and $91 \%$ of the variation in daily runoff volumes. The model also provided accurate predictions of average annual runoff ranging from 33 to $217 \mathrm{~mm}$ for the 15 soil management treatments. Runoff was reduced to a much greater extent by surface cover compared with surface roughness. Surface cover reduced runof curve number by a maximum of 35 units. The maximum reduction in curve number dre to surface roughness was 5 units for shallow tillage and 10 units for deep tillage. Erosion predictions were acceptable but the lack of erosion data for all years in the experimental dars limits the confidence in model output.

Model calibration and validation have provided a set of parameters that can be coupled with historical climate records to provide a long-term perspective of the effects of soil management on runoff and erosion.
\end{abstract}

Keywords: simulation, model, runoff, water balance, curve number.

\section{Introduction}

Alfisols cover approximately one-third of the land in the semi-arid tropics (Kampen and Burford 1980) and are important soils to meet the needs of rapidly growing populations in this region. However, productivity of these soils is low due to interactions between the climate and soil. The current productivity of Alfisols is limited by poor physical characteristics that can compound the effects of a poor season on degradation and production. Low infiltration and resulting 
high runoff and erosion, poor crop establishment and poor crop growth are seen as major limitations for these soils (Smith et al. 1992). The combination of these factors and the inherent rainfall variability in the semi-arid tropics limits the productivity of these soils.

The potential of soil management options to increase inhlitration and thus reduce runoff and erosion from Alfisols was reported by Smith et al. (1992). They found that the application of surface cover (rice straw or farmyard manure) at planting produced large reductions in both runoff and erosion. In contrast, tillage based systems resulted in relatively small differences in runoff and erosion. Their results suggested that the application of surface cover may provide an effective system to improve current productivity and long-term sustainability. However, results by Smith et al. (1992) only looked at effects of soil management options on runoff, erosion and yield for a single growing season (1988). They concluded that further results are required to reach definite conclusions on the long-term effects of soil management on the productivity of Alfisols.

Computer simulation of agricultural systems is essential to determine the long-term effects of management on the water balance, soil erosion and crop yield (Freebairn et al. 1991). A number of comptiter models that operate on a daily time-step have been developed to simulate different aspects of an agricultural system. For example, CREAMS (Knisel 1980), EPIC (Williams 1983) and the CERES family of models (e.g. Jones and Kiniry 1986). A major limitation of these models for studying the effects of soil management on the water balance and productivity are the algorithms that partition rainfall into runoff and infiltration. To predict the effects of soil management on runoff, there is a requirement to estimate how runoff varies with temporal changes in soil water, surface cover, crop cover, and surface changes resulting from tillage.

Models such as CREAMS, EPIC and CERES calculate runoff as a function of rainfall and soil water content only. There is no inclusion of factors such as surface and crop cover or soil surface changes resulting from tillage. Therefore, these models have limited application for analysing the effects of soil management options. In Australia, the PERFECT model (Littleboy et al. 1989, 1992) partially alleviated this limitation by incorporating the effects of crop and surface cover on predicted runoff. Therefore, in PERFECT, runoff is calculated as a function of rainfall, soil water content, crop cover and surface cover. Therefore, PERFECT is a more appropriate model to analyse runoff from cropping systems with complex crop/fallow rotations. Silburn and Freebairn (1992) compared runoff and soil water predictions from CREAMS and PERFECT. They attributed the improvement in runoff and soil water prediction with PERFECT to the inclusion of cover factors into the water balance procedure.

PERFECT was designed to predict runoff, erosion, and crop yield tor some major management options in dryland cropping areas of Australia. That is, sequences of plantings, harvests and stubble management during fallow. In the semi-arid tropics of India, farming practices are different. Tillage is undertaken prior to planting, primarily for water conservation and not for stubble management. Stubble is often removed at harvest and either stored for later use as fodder or re-applied to the soil surface prior to planting the following year. Crops are planted at the start of the monsoon (May or June) and, in some wetter years, a second crop may be planted at the end of the monsoon season. This second 
crop will rely solely on accumulated soil water as the chance of further rainfall is remote.

Current cropping system models are unable to simulate soil management options in Indian farming systems. This paper describes a study that modified and validated the PERFECT model to simulate the effects of soil management option on runoff and erosion. The major requirement for such a study is the simulation of temporal changes in soil water, surface cover, crop cover, and surface changes resulting from tillage and their effects on runoff and erosion. A comparison between predicted and measured runoff and erosion for a range of soil management treatments on a hard-setting Alfisol in the semi-arid tropics, India, will be presented.

\section{Development of the PERFECT-IND model}

We modified runoff prediction, surface cover and on-farm management algorithms in the existing PERFECT model to simulate soil management options in Indian farming systems. This modified version of PERFECT is referred to as PERFECT-IND.

\section{Description of the runoff prediction algorithm}

A common feature of models such as PERFECT, CREAMS, CERES and EPIC is the runoff algorithm that is based on a modified form of the United States Department of Agriculture (USDA) curve number procedure (Soil Conservation Service 1972):

$$
Q=(P-0 \cdot 2 S)^{2} /(P+0 \cdot 8 S)
$$

where $Q$ is total runoff $(\mathrm{mm}), P$ is total rainfall $(\mathrm{mm})$ and $S$ is potential retention $(\mathrm{mm})$.

Equation (1) represents a nonlinear relationship between rainfall and runoff as depicted in Fig. 1.

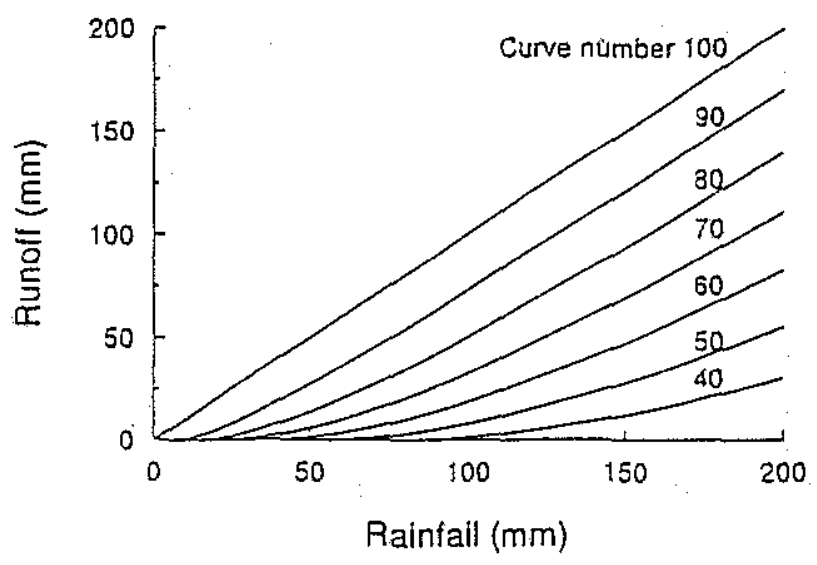

Fig. 1. Relationship between rainfall and runoff in the USDA curve number procedure.

The major input parameter into the USDA curve number method is the runoff curve number (CN). The value of $\mathrm{CN}$ is related to $S$ by

$$
S=25 \cdot 4(1000 / \mathrm{CN}-10) \text {. }
$$

PERFECT-IND incorporates equations from CREAMS that estimate the influence of soil water content on $S$. These relationships are presented in Fig. 2. Effects of soil water content 
on $S$ diminish as antecedent soil water increases. For a wet soil, $S$ is zero and, therefore, runoff volume equals rainfall (equation 1).

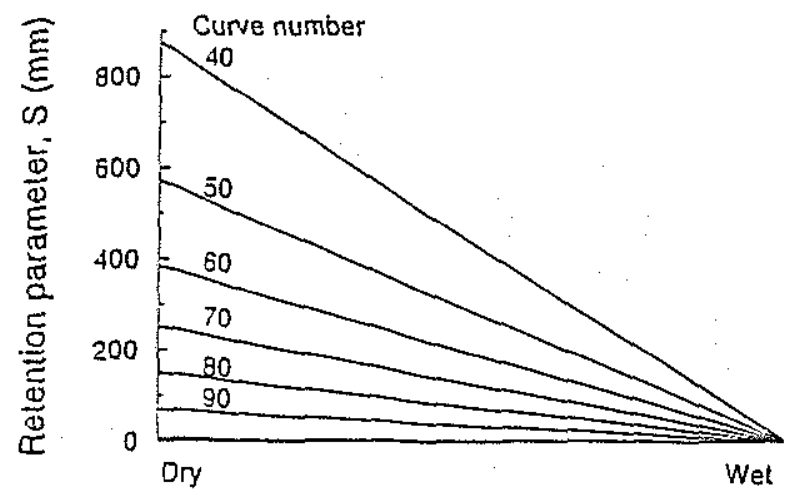

Soil water index

Fig. 2. Effects of soil water content on the retention parameter

$(S)$ in the USDA curve number procedure.

Effects of surface and crop cover on runoff are estimated using a generic form of the function developed in the original PERFECT model:

$$
\mathrm{CN}_{\text {cov }}=\mathrm{CN}_{\text {bare }}-\left(C_{1} \times \mathrm{COVER}\right) \text {, }
$$

where $\mathrm{CN}_{\mathrm{cov}}$ is the value of $\mathrm{CN}$ adjusted for surface cover, $\mathrm{CN}_{\mathrm{bar}}$ is the $\mathrm{CN}$ for soil with no cover, $C_{1}$ is the reduction in CN for each $1 \%$ of cover, and COVER is the surface cover (\%).

The influence of tillage on runoff was incorporated into PERFECT-IND by developing a relationship between curve number and cumulative rainfall since tillage. The basis of this relationship was the work of Freebairn and Gupta (1990) who reported that cumulative rainfall since tillage is an appropriate index of the energy input from rainfall to the soil surface. In PERFECT-IND, the following equation was developed to adjust $\mathrm{CN}$ due to tillage:

$$
\mathrm{CN}_{\text {till }}=\mathrm{CN}_{\text {cov }}+C_{2}\left(\sum \mathrm{RAIN} / C_{3}-1\right) \quad\left(\sum \mathrm{RAIN} \leq C_{3}\right)
$$

where $\mathrm{CN}_{\mathrm{till}}$ is the value of $\mathrm{CN}$ adjusted for effect of tillage, $C_{2}$ is the maximum reduction in CN due to tillage, $C_{3}$ is the cumulative rainfall required to remove tillage eflects and $\mathrm{ERAIN}$ is the cumulative rainfall since tillage $(\mathrm{mm})$.

The relationship in equation (d) shows that, following tillage, $\mathrm{CN}$ is reduced by $C_{2}$ units. Subsequent rainfall increases $\mathrm{CN}$ linearly at a rate dependent on the value of $C_{3}$. Effects of tillage on CN occur until cumulative rainfall since tillage exceeds $C_{3}$.

In PERFECT-IND, the effects of cover and tillage on curve number are incorporated as follows:

(a) the input $\mathrm{CN}_{\text {bare }}$ is adjusted according to cover using equation (3);

(b) $\mathrm{CN}_{\mathrm{cov}}$ is adjusted to account for effects of tillage using equation (4);

(c) equation (2) calculates a value of $\mathrm{S}$ from $\mathrm{CN}_{\text {tilli }}$;

(d) effects of soil water on $\mathrm{S}$ are determined from the relitionship in Fig. 2;

(e) daily runoff is calculated from equation (1).

Since cover and rainfall since tillage are simulated on a daily basis in PERFECT-IND, CN is re-calculated on a daily basis using the adjustments due to cover and tillage (equations 3 and 4). 
Table 1. Relationship between percentage cover and cover weight for different types of surface amendments

\begin{tabular}{|c|c|c|c|c|c|c|c|c|}
\hline \multirow{2}{*}{$\begin{array}{l}\text { Amendment } \\
\text { type }\end{array}$} & \multicolumn{8}{|c|}{ Cover weight cover for residue weight ( $\mathrm{t} / \mathrm{ha})$} \\
\hline & $0 \cdot 0$ & 0.25 & 0.5 & $1 \cdot 0$ & $2 \cdot 5$ & $5 \cdot 0$ & $10 \cdot 0$ & $15 \cdot 0$ \\
\hline Sorghum & $0 \cdot 0$ & $8 \cdot 5$ & $17 \cdot 4$ & $36 \cdot 1$ & $74 \cdot 3$ & $96 \cdot 6$ & $99 \cdot 9$ & $100 \cdot 0$ \\
\hline Castor & 0.0 & $4 \cdot 1$ & $6 \cdot 8$ & $13 \cdot 2$ & $22 \cdot 1$ & $38 \cdot 7$ & $91 \cdot 8$ & $100 \cdot 0$ \\
\hline Millet & 0.0 & $7 \cdot 1$ & $13 \cdot 9$ & $30 \cdot 5$ & $69 \cdot 1$ & 91.9 & $99 \cdot 8$ & $100 \cdot 0$ \\
\hline Rice straw & 0.0 & $24 \cdot 1$ & $47 \cdot 5$ & $92 \cdot 2$ & $98 \cdot 8$ & $100 \cdot 0$ & $100 \cdot 0$ & $100 \cdot 0$ \\
\hline Maize & $0 \cdot 0$ & $9 \cdot 0$ & $13 \cdot 7$ & $18 \cdot 7$ & $47 \cdot 3$ & $96 \cdot 5$ & $100 \cdot 0$ & $100 \cdot 0$ \\
\hline Groundnut & 0.0 & 9.5 & $26 \cdot 2$ & $46 \cdot 2$ & $94 \cdot 7$ & $100 \cdot 0$ & $100 \cdot 0$ & $100 \cdot 0$ \\
\hline Pigeon pea & 0.0 & $4 \cdot 8$ & $7 \cdot 1$ & $11 \cdot 0$ & $21 \cdot 9$ & $39 \cdot 8$ & $88 \cdot 8$ & $100 \cdot 0$ \\
\hline Farmyard manure & 0.0 & $7 \cdot 3$ & $13 \cdot 0$ & $21 \cdot 0$ & $30 \cdot 9$ & $32 \cdot 8$ & $33 \cdot 0$ & $33 \cdot 0$ \\
\hline
\end{tabular}

\section{Estimation of surface cover}

Temporal changes in surface cover can have a large influence on predicted runoff. Of particular importance in this study are the effects of surface amendment on cover. Functions that relate weight of surface amendment to percentage cover for a range of amendments are presented in Table 1. These relationships were required so that the model can predict percentage cover for various weights of amendments. Percentage cover is re-calculated on a daily basis in PERFECT-IND after accounting for amendment decay. As the amendment decays, its affects on $\mathrm{CN}$ and predicted runoff decrease.

\section{Simulating Indian farming systems}

PERFECT-IND contains a number of new functions that were required to mimic Indian farming systems. Specifically,

(i) allowing the user to define dates and amounts of amendment applications;

(ii) permitting the user to specify deep or shallow tillage operations and in-crop tillage;

(iii) removing all above ground biomass at harvest.

\section{Model calibration and validation \\ Description of field data}

Runoff, soil erosion, soil moisture and agronomic data were collected from 45 experimental plots for the period 1988-1992 on an Alfisol soil at ICRISAT Centre, Patancheru, India. This experiment is a replicated plot trial for 15 management treatments comprising nine tillage and amendment treatments and six perennial ley treatments. The tillage and amendment treatments were three tillage treatments (zero tillage, shallow tillage to $10 \mathrm{~cm}$ and deep tillage to $20 \mathrm{~cm}$ ) combined with three amendment treatments (bare, farmyard manure at $15 \mathrm{t} / \mathrm{ha}$ and rice straw at $5 \mathrm{t} / \mathrm{ha}$ ). The six perennial treatments were combinations of perennial pigeon pea (Cajanus cajan), verano stylo (Stylosanthes hamata), and buffel grass (Cenchrus ciliaris). Smith et al. (1992) provide the rationale, description and initial results from the experiment.

Runoff was measured with tipping buckets coupled to a data logger (Smith et al. 1992). Runoff data for the period 1989-1992 were used to test the PERFECT-IND model. Suspended sediment and bedload in runoff from the plots were only measured in the 1992 season. Bedload was collected in a trough and measured following each runoff event. Suspended sediment was measured using a flow splitting device that sampled approximately $0 \cdot 1 \%$ of total runoff flow.

The climate of the site is characterized by the summary of rainfall, temperature, evaporation and radiation for 1989-1992 in Table 2. Average annual rainfall for the study period was $818 \mathrm{~mm}$. Over $93 \%$ of annual rainfall occurred in the six months from May to October (monsoon season). Rainfall only exceeded evaporation in the wettest months of July and August. The hottest months of April and May occurred before the monsoon. Both temperature and radiation decreased during the monsoon months due to increased cloud cover. 
Table 2. Average monthly rainfall, maximum and minimum temperature, evaporation and radiation at the experinental site for the period 1989-1992

\begin{tabular}{|c|c|c|c|c|c|}
\hline Month & $\begin{array}{c}\text { Rain } \\
(\mathrm{mm})\end{array}$ & $\begin{array}{l}\text { Max. } \\
\text { temp. } \\
\left({ }^{\circ} \mathrm{C}\right)\end{array}$ & $\begin{array}{l}\text { Min. } \\
\text { temp. } \\
\left({ }^{\circ} \mathrm{C}\right)\end{array}$ & $\begin{array}{l}\text { Pan } \\
\text { evap. } \\
\text { (mm) }\end{array}$ & $\begin{array}{c}\text { Solar } \\
\text { rad. } \\
\left(\mathrm{m} \mathrm{J} / \mathrm{m}^{2} \cdot \mathrm{day}\right)\end{array}$ \\
\hline Jantuary & $1 \cdot 0$ & 28.8 & $13 \cdot 6$ & $15 \cdot 4 \cdot 4$ & $17 \cdot 3$ \\
\hline February & $0 \cdot 0$ & $32 \cdot 3$ & $15 \cdot 4$ & $180 \cdot 9$ & $19 \cdot 9$ \\
\hline March & $17 \cdot 1$ & $35 \cdot 1$ & $19 \cdot 5$ & $262 \cdot 8$ & $21 \cdot 4$ \\
\hline April & $14 \cdot 7$ & 37.8 & $22 \cdot 7$ & $302 \cdot 5$ & $22 \cdot 5$ \\
\hline May & $6.3 \cdot 6$ & 38.2 & 24.8 & $323 \cdot 3$ & $22 \cdot 1$ \\
\hline June. & $136 \cdot 4$ & $32 \cdot 9$ & $23 \cdot 3$ & $213 \cdot 4$ & $17 \cdot 7$ \\
\hline July & $197 \cdot 0$ & $30 \cdot 2$ & $22 \cdot 5$ & $164 \cdot 7$ & $16 \cdot 2$ \\
\hline Aligust & $174 \cdot 9$ & $29 \cdot 1$ & $22 \cdot 0$ & $133 \cdot 9$ & $15 \cdot 1$ \\
\hline September & $13 \cdot 4 \cdot 3$ & $30 \cdot 2$ & $21 \cdot 8$ & $135 \cdot 3$ & $17 \cdot 9$ \\
\hline October & $59 \cdot 8$ & $30 \cdot 5$ & $19 \cdot 5$ & $146 \cdot 4$ & $18 \cdot 0$ \\
\hline November & $19 \cdot 3$ & $28 \cdot 6$ & $17 \cdot 0$ & $135 \cdot 3$ & $15 \cdot 8$ \\
\hline December & $0 \cdot 0$ & $27 \cdot 1$ & $13 \cdot 2$ & $132 \cdot 4$ & $16 \cdot 1$ \\
\hline
\end{tabular}

\section{Derivation of PERFECT-IND weather and soil inputs}

On-site rainfall was measured on a $1 \mathrm{~min}$ time-step and accumulated into daily totals to provide a daily rainfall record for PERFECT-IND. Daily temperature, radiation and evaporation data were obtained from the ICRISAT meteorological station, approximately $1 . \overline{\mathrm{km}}$ from the experimental site.

Wherever possible, measured values of soil physical properties were input in PERFECT-IND. The use of measured values minimizes problems that can occur when calibrating a large number of interrelated parameters.

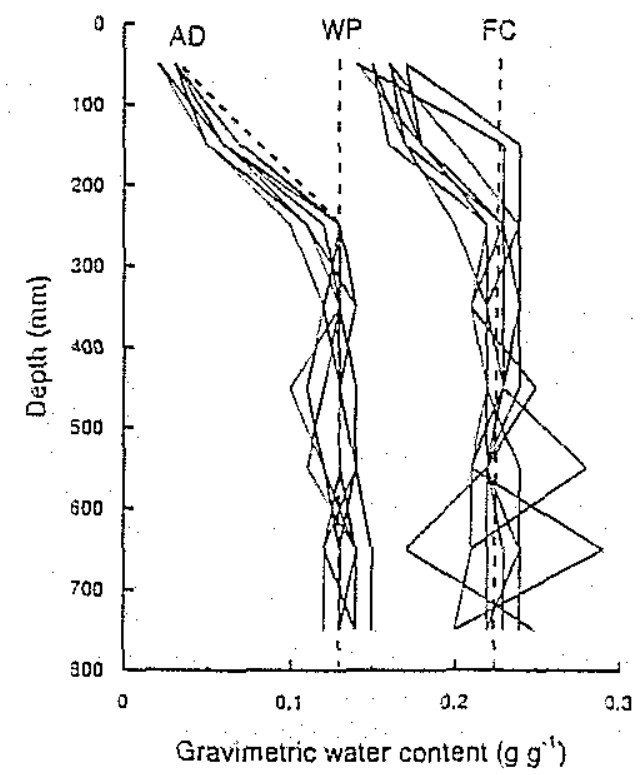

Fig. 3. Measured wettest and driest soil moisture profiles (\% gravimetric) for each treatment and assumed air-dry (AD), wilting point (WP) and tield capacity (FC).

The plant-available water capacity of the Alfisol at the experimental site was determined by plotting the wettest and driest soil moisture measurements for eich measurement depth (Fig. 3). From these data, the assumed gravimetric lower and upper limits were 0.13 and $0.225 \mathrm{~g} / \mathrm{g}$ respectively. An air-dry component was included for the top $25 \mathrm{~cm}$ of soil. From these data, the plant-available water capacity was estimated at $115 \mathrm{~mm}$ to a depth of $80 \mathrm{~cm}$. 
Soil water content at saturation was inferred from measured bulk density using the relationship

$$
\mathrm{SAT}=0 \cdot 95(1 \cdot 0-\mathrm{BD} / 2 \cdot 65)
$$

where SAT is the saturation water content $(\theta V)$ and BD is the bulk density $\left(\mathrm{g} / \mathrm{cm}^{3}\right)$. Soil evaporation parameters CONA and $U$ (Ritchie 1972) were held constant at 4.0 and 8.0 respectively for all simulations.

\section{Simulation procedure-tillage treatments}

Two techniques, namely model calibration and model validation were applied in this study. Model calibration is a technique where model parameters are systematically adjusted to minimize the differences between measured and simulated data. Model validation is the comparison of measured and estimated data without any adjustment of model parameters.

In this study, model calibration was performed using a portion of an experimental dataset to derive values for the $\mathrm{CN}_{\mathrm{barc}}, C_{1}, C_{2}$ and $C_{3}$ coefficients in equations (3) and (4). The root mean square error (RMSE) between measured and predicted runoff was calculated to quantify goodness of fit for all model calibrations. Calibration involved the systematic adjustment of each parameter using the method of steepest descent. The calibrated value of each parameter occurred at the minimum value of RMSE.

The strategy for deriving values for the $\mathrm{CN}_{\text {bare }}, C_{1}, C_{2}$ and $C_{3}$ coefficients in equations (3) and (4) was:

(a) the value of $\mathrm{CN}_{\text {bare }}$ in equation (3) (i.e. $\mathrm{CN}$ for no amendment or tillage) was calibrated using data for the zero tillage with no amendment treatment;

(b) the value of $C_{1}$ in equation (3) was obtained by calibration with data from the zero tillage with straw-amendment treatment;

(c) values of $C_{3}$ and $C_{4}$ in equation (4) for shallow tillage were derived using data from the shallow tillage with no amendment treatment;

(d) values of $C_{3}$ and $C_{4}$ in equation (4) for deep tillage were calibrated using data from the deep tillage with no amendment treatment.

Therefore, four of the nine tillage and amendment treatments were used to derive values for the $\mathrm{CN}_{\text {barc }}, C_{1}, C_{2}$ and $C_{3}$ coefficients in equations (3) and (4). The model was then validated on the remaining five treatments in the dataset by using the calibrated curve number relationships. The validation treatments were zero tillage (plus manure), shallow tillage (plus straw), shallow tillage (plus manure), deep tillage (plus straw) and deep tillage (plus manure). Runoff for these tillage and amendment treatments was estimated by inputting the curve number for bare, untilled conditions into PERFECT-IND and applying the relevant cover and tillage relationships.

Crop water use was predicted using the SORKAM model (Rosenthal et al. 1989) that is contained within PERFECT and PERFECT-IND.

\section{Simulation procedure-perennial treatments}

Perennial treatments were simulated with crop water use predicted by using crop factors. An initial crop factor was determined from average cover during the growing season. This crop factor was adjusted to calibrate PERFECT-IND for each perennial treatment. The perennial treatments including Stylosanthes hamata required re-calibration of the $\mathrm{CN}_{\text {barc }}$ parameter.

\section{Results from model calibration/validation}

\section{Curve number relationships}

The curve number for the zero tillage with no cover treatment ( $\mathrm{CN}_{\text {bare }}$ in equation 3 ) is 94 . The value of $C_{1}$ in equation (3) obtained by calibration is 0.35 . That is, curve number is reduced by 0.35 units for each $1 \%$ of cover with a maximum reduction in curve number due to cover of 35 units. The equation that relates curve number to cover is 


$$
\mathrm{CN}_{\text {cov }}=\mathrm{CN}_{\text {barc }}-0 \cdot 35(\mathrm{COVER})
$$

Calibrated values of $C_{2}$ and $C_{3}$ in equation (4) varied with tillage type. For shallow tillage to $10 \mathrm{~cm}$, the curve number is reduced by 5 units following tillage $\left(\mathrm{C}_{2}\right)$. Rainfall after tillage causes curve number to increase linearly by 5 units until $200 \mathrm{~mm}$ of rainfall is received $\left(C_{3}\right)$. The equation that relates curve number to shallow tillage is

$$
\mathrm{CN}_{\text {till }}=\mathrm{CN}_{c o v}+5\left(\sum \mathrm{RAIN} / 200\right)-1 \quad\left(\sum \mathrm{RAIN} \leq 200\right)
$$

For deep tillage to $20 \mathrm{~cm}$, the curve number is reduced by 10 units following tillage $\left(C_{2}\right)$. Curve number increases linearly by 10 units until $400 \mathrm{~mm}$ of rainfall has occurred since tillage $\left(C_{3}\right)$. The equation that relates curve number to deep tillage is

$$
\mathrm{CN}_{\text {till }}=\mathrm{CN}_{\text {cov }}+10\left(\sum \mathrm{RAIN} / 400-1\right) \quad\left(\sum \mathrm{RAIN} \leq 400\right)
$$

The calibrated curve number for the perennial treatments that included Stylosanthes hamata was 83 .

Table 3. Root mean square error (RMSE), number of observations $(n)$, and observed and

\begin{tabular}{|c|c|c|c|c|}
\hline \multirow[t]{2}{*}{ Treatment } & \multicolumn{2}{|c|}{ Daily runoft } & \multicolumn{2}{|c|}{ Average annual runoff } \\
\hline & $\begin{array}{l}\text { RMSE } \\
(\mathrm{mm})\end{array}$ & $n$ & $\begin{array}{l}\text { Predicted } \\
\text { (mm) }\end{array}$ & $\begin{array}{l}\text { Observed } \\
(\mathrm{mm})\end{array}$ \\
\hline Zero tillage, bare soil & 6 & 111 & 210 & 217 \\
\hline Zero tillage+manure & 5 & 88 & 132 & 133 \\
\hline Zero tillage+straw & 4 & 57 & 70 & 67 \\
\hline Shallow tillage, bare soil & 7 & 108 & 195 & 205 \\
\hline Shallow tillage + manure & 6 & 83 & 124 & 120 \\
\hline Shallow tillage+straw & 5 & 61 & 68 & 73 \\
\hline Deep tillage, bare soil & 7 & 101 & .172 & 173 \\
\hline Deep tillage-manure & 5 & 83 & 114 & 124 \\
\hline Deep tillage+straw & 5 & 59 & 64 & 66 \\
\hline Cenchrus & 4 & 50 & 55 & 55 \\
\hline Cenchrus+Stylo & 4 & 49 & 74 & 74 \\
\hline Pigeon pea & 5 & 63 & 122 & 122 \\
\hline Pigeon pea+Stylo & 4 & 30 & 38 & 38 \\
\hline Pigeon pea+Cenchrus+Stylo & 4 & 33 & 45 & 45 \\
\hline Stylo & 3 & 30 & 38 & 33 \\
\hline
\end{tabular}
predicted average annual runoff using the PERFECT model for the nine tillage and amendment treatments and six perennial treatments

\section{Runoff predictions}

A comparison of predicted and observed runoff for the 15 treatments is presented in Table 3. Values of RMSE for the (1:1) line ranged from 3 to $7 \mathrm{~mm}$. The range of RMSE was similar to those reported by Littleboy et al. (1992) for a range of sites in subtropical Australia. Large differences iu runoff due to surface treatment were accurately predicted (measured average annual runoff for 
the 15 tillage and perennial treatments ranged from 33 to $217 \mathrm{~mm} /$ year). The model provided very accurate predictions of average annual runoff for both the calibration and validation treatments.
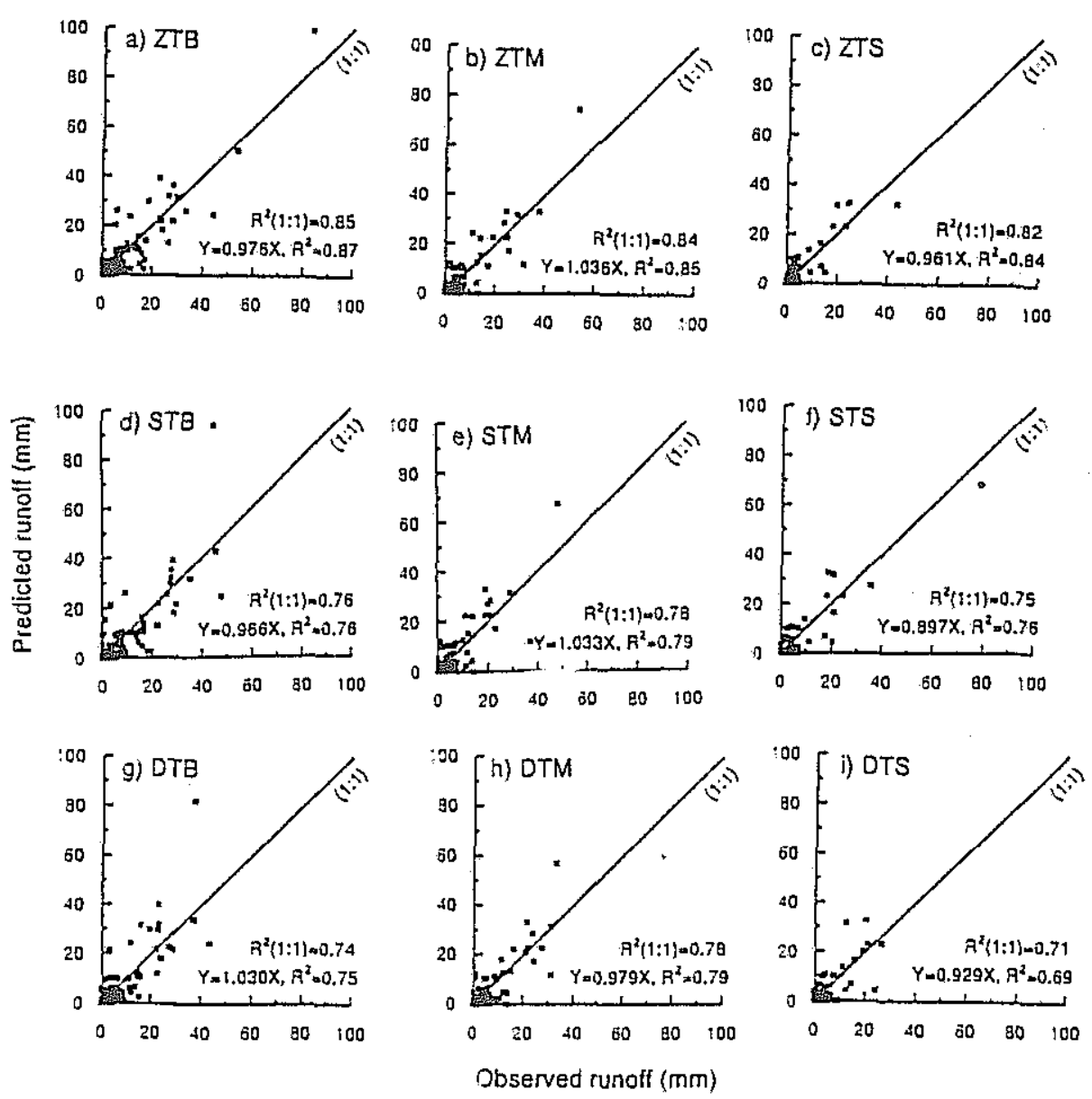

Fig. 4. Predicted and observed daily runoff volumes for (a) zero tillage, bare soil (ZTB); (b) zero tillage+manure (ZTM); (c) zero tillage+straw (ZTS); (d) shallow tillage, bare soil (STB); (e) shallow tillage+manure (STM); $(f)$ shallow tillage + straw (STS); $(g)$ deep tillage, bare soil (DTB); $(h)$ deep tillage+manure (DTM); and (i) deep tillage+straw (DTS).

Actual and estimated daily runoff volumes for the 15 treatments are shown in Figs 4 and 5 . The model explained $71-91 \%$ of the variation in daily runoff volumes. There was no evidence of the model consistently overpredicting or underpredicting daily runoff volume, with model predictions uniformly scattered around the 1:1 line. However, one large event was significantly overpredicted for bare treatments with shallow tillage or deep tillage.

\section{Erosion predictions}

Measured and estimated erosion for the nine tillage and amendment treatments during 1992 are shown in Table 4. Although both the sample size and volumes of 
measured sediment are limited, model predictions were similar to the measured data across the range of tillage and amendment treatments. The perennial treatments were omitted due to negligible amounts of measured sediment.

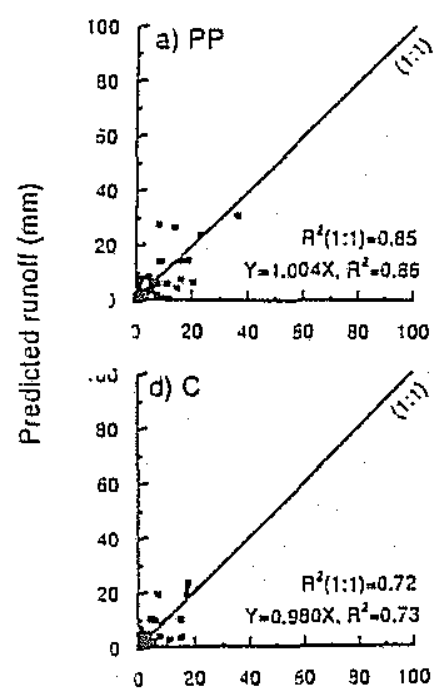

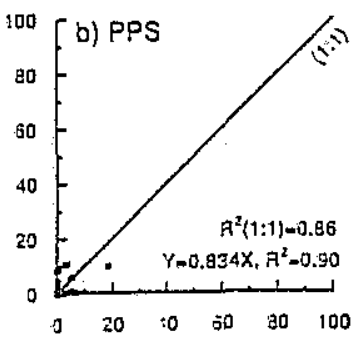

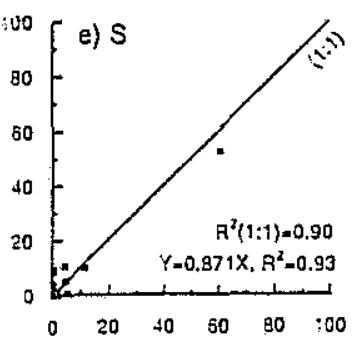

Observed runoff (mm)
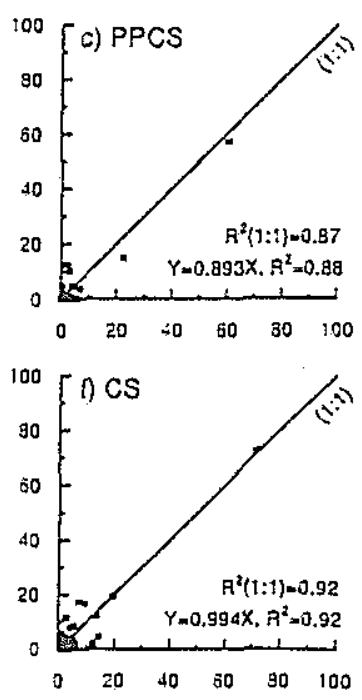

Fig. 5. Predicted and observed daily runoff volumes for $(a)$ pigeon pea (PP); (b) pigeon pea+stylo (PPS); (c) pigeon pea+cenchrus+stylo (PPCS); $(d)$ cenchrus (C); $(e)$ stylo (S); and $(f)$ cenchruststylo (CS).

Table 4. Observed and predicted erosion ( $t / \mathrm{ha}$ ) during 1992 for the nine tillage and amendment treatments

\begin{tabular}{lcc}
\hline \multicolumn{1}{c}{ Treatment } & Predicted & Observed \\
\hline Zero tillage, bare soil & $6 \cdot 0$ & $5 \cdot 7$ \\
Zero tillage+manure & $3 \cdot 2$ & $4 \cdot 8$ \\
Zero tillage+straw & $2 \cdot 6$ & $2 \cdot 5$ \\
Shallow tillage, bare soil & $5 \cdot 1$ & $5 \cdot 2$ \\
Shallow tillage+manure & $3 \cdot 1$ & $2 \cdot 3$ \\
Shallow tillage+straw & $2 \cdot 6$ & $2 \cdot 1$ \\
Deep tillage, bare soil & $4 \cdot 5$ & $4 \cdot 8$ \\
Deep tillage+manure & $3 \cdot 0$ & $3 \cdot 9$ \\
Deep tillage+straw & $2 \cdot 6$ & $2 \cdot 3$ \\
\hline
\end{tabular}

\section{Discussion and conclusions}

The experimental data revealed large differences in runoff as a consequence of various soil management strategies. Measured average annual runoff ranged from 33 to $217 \mathrm{~mm}$ for the 15 treatments. Inclusion of rudimentary relationships into PERFECT-IND to modify curve number with surface cover and/or tillage has successfully modelled the large variations in runoff between these treatments.

A linear relationship between curve number and surface cover and a linear relationship between curve number and cumulative rainfall since tillage allowed PERFECT-IND to successfully predict the effects of surface cover and tillage on 
runoff. PERFECT-IND explained between 71 and $91 \%$ of the variation in daily runoff volumes due to tillage and surface cover applications without any further calibration of the model.

Surface cover was shown to reduce curve number by a maximum of 35 units. On the other hand, shallow and deep tillage operations would recluce curve number by a maxinum of only 5 and 10 units respectively. Therefore, at this site, effects of surface cover on runoff were much greater than differences in runoff due to tillage. This trend was also clearly evident in the measured runoff data in Table 3. For zero tillage, the addition of straw reduced average annual runoff from 217 to $67 \mathrm{~mm} /$ year. The effects of tillage on runoff were much smaller. The deep tillage bare treatment produced $173 \mathrm{~mm} / \mathrm{year}$ of runoff compared with $217 \mathrm{~mm} /$ year for the zero tillage bare treatment.

Differences in curve number due to tillage declined with rainfall. This trend was expected based on the work reported by Freebairn and Gupta (1990), who related infiltration rate to rainfall since tillage. They found that infiltration decreased, and therefore runoff was higher as cumulative rainfall since tillage increased. A previous analysis of a single years data in the dataset used in this paper showed similar trends (Yule et al. 1990). In another study, Somaratne and Smettem (1993) reported differences in surface hydraulic properties due to tillage on an Alfisol soil. These authors attributed the decrease in infiltration during the cropping cycle to consolidation of the soil surface by rainfall.

The re-calibration of the curve number parameter for the perennial treatments including Stylosanthes hamata was not unexpected. Higher soil biological activity would allow for increased infiltration and hence, a lower curve number.

The curve number relationships that were incorporated into PERFECTIND may be site specific and may need to be determined experimentally for other environments. In this study, a comprehersive dataset was analysed to determine these relationships. However, such datasets rarely exist, but the use of rainfall simulators could provide a relatively simple technique to determine these relationships for a wider range of soils, soil managements and environments. Analysis of rainfall simulator data from this site is described in Part II of this study.

The results of model calibration and validation presented in this paper have demonstrated the robustness of PERFECT-IND in this environment. The accurate prediction of runoff has greatly enhanced our confidence in the model. The value in testing a model at an experimental site is to derive a set of parameters that can be confidently coupled with historical climate data to obtain a long-term perspective of the water balance, soil erosion and crop growth in an agricultural system. Extrapolation of these short-term experimental data to long-term predictions is described in Parts III and IV of this study.

\section{Acknowledgments}

We thank the staff associated with the field project including S. T. Sriniwasan, P. J. George, L. S. Jangawad, M. Ali, G. P. Kumar and N. Ramaswany and P. Kistiah for maintaining and operating the experiment.

\section{References}

Freebairn, D. M., and Gupta, S. C. (1990). Microrelief, ranfall and cover elfects on infiltration. Soil and Tillage Research 16, $30 \mathrm{~T}-2 \mathrm{~T}$. 
Freebairn, D. M., Littleboy, M., Smith, G. D., and Coughlan, K. J. (1991). Optimising soil surface management in response to climatic risk. In "Climatic Risk in Crop Production: Mlodels and Management for the Semiarid Tropics and Subtropics'. (Eds R. C. Muchow and J. A. Bellamy.) pp. 283-305. (CAB International: Wallingford, UK.)

Jones, C. A., and Kiniry, J. R. (1986). 'CERES-MAIZE: A Simulation Model of Maize Growth and Development.' (A\&M University Press: Texas.)

Kampen, J., and Burford, J. R. (1980). Production systems soil-related constraints and potentials in the semi-arid tropics with special reference to India. In 'Priorities for Alleviating Soil Related Constraints to Food Production in the Tropics'. Symposium Proceedings, IRRI, Los Banos, Laguna, Philippines. pp. 141-5.

Knisel, W. G. (1980). 'CREAMIS: A Field-Scale Model for Chemicals, Runoft, and Erosion from Agricultural Management Systems.' United States Department of Agriculture, Conservation Research Report 26.

Littleboy, M., Silburn, D. M., Freebairn, D. M., Woodruff, D. R., and Hammer, G. L. (1989). PERFECT, A computer simulation model of Productivity, Erosion, Runoff and Functions to Evaluate Conservation Techniques. Queensland Department of Primary Industries, Bulletin QB89005.

Littleboy, M., Silburn, D. M., Freebairn, D. M., Woodruff, D. R., Hammer, G. L., and Leslie, J. K. (1992). Impact of soil erosion on production in cropping systems. I Development and validation of a simulation model Australian Journal of Soil Research 30, 757-74.

Ritchie, J. T. (1972). A model for predicting evaporation from a row crop with incomplete cover. Water Resources Research 8, 1204-13.

Rosenthal, W. D., Vanderlip, R. L., Jackson, B. S., and Arkin, G. F. (1989). SORKAM: A Grain Sorghum Crop Growth Model. Texas Agricultural Experimental Station Computer Software Documentation Series, MP1660, Texas A\&M University, Texas.

Silburn, D. M., and Freebairn, D. M. (1992). Evaluations of the CREAMS Model. III. Simulation of the hydrology of Vertisols. Australian Journal of Soil Research 30, 547-64.

Smith, G. D., Coughlan, K. J., Yule, D. F., Laryea, K. B., Stivastava, K. L., Thomas, N. P., and Cogle, A. L. (1992). Soil management options to reduce runoff and erosion on a hardsetting Alfisol in the semi-arid tropics. Soil and Tillage Research 25, 195-215.

Soil Conservation Service (1972). 'National Engineering Handbook.' Section 4. (United States Department of Agriculture.)

Somaratne, N. M., and Smettem, K. R. J. (1993). Effect of cultivation and raindrop impact on the surface hydraulic properties of an Alfisol under wheat. Soil and Tillage Research 26, $115-25$.

Williams, J. R. (1983). 'EPIC, The Erosion-productivity Impact Calculator, Volume 1.' Model Documentation, Agricultural Research Service, United States Department of Agriculture.

Woodruf, D. R., and Tonks, J. (1983). Relationship between time of anthesis and grain yield of wheat genotypes with differing developmental patterns. Australian Journal of Agricultural Research 34, 1-11.

Yule, D. F., Smith, G.D., and George, P. J. (1990). Soil management options to increase infiltration in Alfisols. Proceedings, International Symposium on Water Erosion, Sedimentation and Resource Conservation. 9-13 October 1990, Dehradun, India, Central Soil and Water Conservation Research and Training Institute, Dehradun, Uttar Pradesh, India. 